\title{
Sjamanen i stjerneregn: En reise til Asias sentrum
}

\author{
B. MiRee Abrahamsen \\ Bergen: Vigmostad \& Bjørke AS 2019. \\ 496 sidor. ISBN 9788241918469
}

Anmeldt av Ingvar Svanberg [Institutet för Rysslands- och Eurasienstudier, ingvar.svanberg@gmail.com]

Schamanism är samlingsbeteckning för en religiös uttrycksform som förekommer bland många folk i Asien, Afrika och på den amerikanska dubbelkontinenten. Utövaren, schamanen (ursprungligen ett evenkiskt ord), söker kontakt med den osynliga andevärlden som bebor landskapet i människornas närhet och kan antingen påverka den eller kommunicera med den. Denna religionsform klumpas ofta samman under benämningen animism, men faktum är att religiösa utövare som kan betecknas som schamaner förekommer även bland exempelvis buddhister (mongoler, tibetaner) och muslimer (kazaker, kirgizer) i Asien. Särskilt sedan den bästsäljande antropologen Carlos Castanedas böcker för drygt 50 år sedan för en vid läsekrets introducerade en schaman bland yaquinfolket, vars "lära» uppskattades i nyandliga kretsar, har intresset varit stort. Det har utvecklats vad som närmast kan kallas en schamanturism där andliga sökare gärna vill resa till områden med utövande schamaner och få ta del av deras insikter. Kulturell appropiering är inte heller ovanligt där västerlänningar på olika sätt ikläder sig schamanens identitet och själv praktiserar "läran».

När Sovjetunionen föll samman 1991 och det blev möjligt att resa till bergstrakterna i Sibirien, som bebos av en rad små turkiska och tungusiska folk som fortfarande utövar schamanism, styrde många kosan dit. Schamaner i Tuva, ett litet bergsland i ett bortglömt hörn av Sibirien som bebos av turkisktalande nomader, har blivit ett populärt resmål. Från att ha varit förföljda under sovjetstyret har schamanerna nu tillåtits komma in från kylan. Resebyråer erbjuder "esoteriska resor» till Tuva där man får besöka schamaner, som inte bara delar med sig av sina erfarenheter och kunskaper, utan också tillhandahåller enskilda konsultationer rörande hälsa och framtida öde. Yttervärldens intresse för den tuvinska schamanismen har säkert bidragit till denna revitalisering och det stärkta självförtroendet hos dess utövare.

De avlägsna bergstrakterna, där människor fortfarande lever som hästnomader och deras religiösa specialister utövar schamanism, har förstås en särskild turistisk lockelse. En som fascinerats och därför rest dit är B. MiRee Abrahamsen. Författaren är 


\section{4 | INGVAR SVANBERG}

vad jag förstår en välkänd skribent i Norge med en lång rad romaner och andra böcker bakom sig. Hon har också en brokig och gedigen utbildning. Under senare år har hon publicerat en rad reseberättelser, inspirerade av vidsträckta färder i Sibirien, varav volymen med den vackra titeln Sjamanen $i$ stjerneregn: En reise til Asias sentrum förmodligen är den mest uppmärksammade. Ordet schamanism i titeln attraherar givetvis en bred publik, och boken är inte bara en skildring av en färd till Tuva och närbelägna Chakassien, utan också en personlig skildring av schamanismen som religiöst fenomen. Till skillnad från många andra västerländska resenärer till denna del av Sibirien behärskar hon ryska, vilket gett henne möjligheter att komma människorna på plats närmare.

Abrahamsens bok följer två spår. Dels är det en regelrätt reseberättelse där vi får stifta bekantskap med Tuva och dess invånares vardag, såsom den tedde sig 2018 . Anekdoter och det personligt upplevda varvas med historiska återblickar. Tuva var under sovjettiden oåtkomligt för utlänningar, med undantag för enstaka östtyska och ungerska forskare, men efter att imperiet bröt samman har världen börjat uppmärksamma den lilla republiken (en gång till och med självständigt under namnet Tuvinska folkrepubliken (Tannu-Tuva), något som behandlas alltför kortfattat). Landet är inklämt mellan Ryssland och Mongoliet, där det talas ett specifikt sydsibiriskt turkiskt språk. Särskilt den egenartade strupsången har fascinerat många i väst och flera framträdande artister från Tuva har under senare år kommit till Skandinavien och uppträtt vid folkmusikfestivaler. Schamanismen, som finns parallellt till lamabuddhismen i Tuva, utövar uppenbarligen en särskild dragkraft, något som Abrahamsen också fascinerats av, och därför undersöker hon varför schamanismen i vår moderna tid fortlever och attraherar inte bara representanter för lokalkulturen, utan också sökare från hela världen. Detta blir ett personligt utforskande av schamanismen. Berättelsen blir till en bildningsresa i tidigare okänt land. Längs vägen serveras vi en mängd intressanta och spännande detaljer. Texten kompletteras också med en rad illustrationer.

Ämnets särskilda tjusning och att texten författats i en personlig, litterärt essäistisk stil med korta kapitel borgar för att boken kommer att läsas av en större krets än vad som är fallet med exempelvis antropologiska eller religionsvetenskapliga avhandlingar. Boken avslutas med en omfattande käll- och litteraturförteckning över material som konsulterats vid författandet. 